\title{
Stress urinary incontinence and counseling and practice of pelvic floor exercises postpartum in low-income Hispanic women
}

Haleh Sangi-Haghpeykar • Pantea Mozayeni •

Amy Young • Paul M. Fine

Published online: 18 April 2008

(C) International Urogynecology Journal 2008

\section{Erratum to: Int Urogynecol J}

DOI 10.1007/s00192-007-0438-1

The name of the first author was spelled incorrectly. The correct spelling is that given here: Haleh Sangi-Haghpeykar

The online version of the original article can be found at http://dx.doi. org/10.1007/s00192-007-0438-1.

H. Sangi-Haghpeykar $(\bowtie) \cdot$ P. Mozayeni $\cdot$ A. Young $\cdot$ P. M. Fine Department Ob/Gyn, Baylor College of Medicine,

1709 Dryden Rd.,

Houston, TX 77030, USA

e-mail: halehs@bcm.tmc.edu 